Article

\title{
Recycled Waste Powders for Alkali-Activated Paving Blocks for Urban Pavements: A Full Laboratory Characterization
}

\author{
Piergiorgio Tataranni $(D)$ \\ Department of Civil, Chemical, Environmental and Materials Engineering, University of Bologna, \\ 40136 Bologna, Italy; piergiorg.tataranni2@unibo.it
}

Received: 31 October 2019; Accepted: 21 November 2019; Published: 22 November 2019

\begin{abstract}
Paving blocks are today a popular paving solution for urban surfaces. Considering the wide variety of products currently on the market, it is possible to build pavements that differ in terms of functionality, bearing capacity, skid resistance, visual impact, and aesthetic integration with the surrounding landscape. Interlocking concrete paving block is the most common construction technology considering its low cost and its easy installation. Different wastes and second-hand materials have recently been tested in order to completely or partially replace the raw materials used for the production of paving blocks. In this paper, a waste basalt powder is used for the production of alternative paving blocks through the alkali-activation process. Two different synthetic blocks were produced, with and without aggregates. Taking into account the EN 1338 standard for concrete paving blocks, a complete laboratory characterization is proposed for the two experimental blocks. Tests highlighted positive results and downsides that need to be optimized in order to convert the laboratory production to an industrial scale.
\end{abstract}

Keywords: paving blocks; alkali-activated materials; urban pavements; waste powders; recycled materials

\section{Introduction}

Recent studies have highlighted the dramatic development of the urban land cover phenomenon, given by the actual era of unprecedented global urbanization [1,2]. The growth in the size of cities has completely changed the original concept of urbanization, making the modern urban area a complex system of paved surfaces [3,4]. Everyday people spend countless hours of their lives in the road network and considering the multitude of activities carried out on urban pavements, these can no longer be treated as simple infrastructures [5,6]. The intricacy of the modern urbanization has led to a differentiation in the urban pavement network, which is currently composed by lanes for powered vehicles, special lanes, bike, and pedestrian lanes, parking areas, sidewalks and squares [7]. Studies revealed that around the $95 \%$ of road users wish to have a clear and instant visual identification of the different paths, which compose the urban roads network [8].

The need to differentiate the pavements according to the final intended use has created different paving solutions, in terms of construction technology and materials [9]. From the traditional bituminous pavements, the new design solutions encompass the application of special asphalt concretes (porous or colored asphalt mixtures), paving blocks, cobblestone pavements or special ultrathin surface layers [10].

Paving blocks represent a suitable alternative to cobblestone or bituminous sidewalks, bike or pedestrian lanes and to historic pavements, especially in old cities centers [11,12]. These are commonly employed as paving solution due to the relatively low production and laying costs [13]. Furthermore, considering the possible use of a wide range of materials and craft different shapes, paving blocks 
have a large applicability in civil constructions [14]. The most common paving blocks are produced in cement concrete, where the mix design is a function of the final performance required for the block. Lightweight concrete is often used for pedestrian and outdoor pavements. Porous concrete is generally required for permeable pavements (i.e., parking areas) and high-performance cement concrete is suitable for heavy load traffic pavements or heavy load storage areas [15-18].

According to the latest estimates, the constructions sector is responsible for $36 \%$ of global energy use and around $40 \%$ of CO2 emissions [19]. Taking into account the growing interest for environmental issues such as the limitation of non-renewable resources and the emission of greenhouse gasses related to human activities, the construction's sector has been strongly affected by eco-friendly policies. In the last years, an increasing demand for alternative and sustainable materials has been registered to promote and to develop the so-called novel "green constructions" [20-23]. The recycling of waste materials seems to be a viable solution for the production of new construction materials. The re-uses of wastes, industrial byproducts and second-hand materials can couple the advantages given by the conservation of resources to the inclusion of materials destined for landfills in the production cycle of a new product [24]. This approach is perfectly in line with the circular economy concept, where the objective is the reduction of the environmental footprint, also related to the construction's sector. Furthermore, when scientifically proven, the re-use of waste materials does not compromise the construction standards $[25,26]$. Thus, researchers from all over the world are focusing on experimental applications of wastes as construction materials, being the recycling the new frontier of the civil engineering [27].

The paving blocks market is not further from this phenomenon. The cement concrete is the most common constitutive material for modular elements, and the Portland cement production is today under investigation from an environmental point of view [28]. Andrew calculated the $\mathrm{CO} 2$ emission from cement production in 2017 as $1.48 \mathrm{Gt}$, corresponding to about $8 \%$ of the carbon dioxide globally produced [29]. These emissions derived from the combined action of the chemical reaction involved in the Portland cement production (formation of clinker) and the power needed to heat the raw materials over $1000{ }^{\circ} \mathrm{C}$. Over the years, attempts have been made to partially or completely substitute the Portland cement with sustainable materials in order to reduce the environmental footprint of the concrete production [30,31]. The literature shows several applications of alternative materials, as paving block constituents. Most of the studies concentrated on the substitution of natural aggregates with recycled materials [32]. Different researches evaluated the possible addition of Construction and Demolition Wastes (CDW) within concrete paving blocks [33] and positive outcomes were verified for the replacement of fine aggregates with recycled materials (i.e., dragged sediments, waste marble, ceramic tiles, etc.) [34-36]. However, a relatively low number of studies focused on the use of byproducts or waste cementitious materials as binding agents, in order to reduce the cement content of the final product [37-39]. The advantage given by the replacement or the reduction of Portland cement with alternative materials would be remarkable, considering the impact of the cement production and the waste disposal on the environment.

Thus, in the case presented here, alternative paving blocks were produced through the alkali-activation process of a waste basalt powder, without the addition of Portland cement. Starting from the laboratory characterization of the alkali-activated paste, two different versions of modular elements were cast: with and without aggregates. The evaluation of the physical, mechanical, and functional properties of the paving blocks was based on laboratory tests suggested by the EN 1338 standard, which specifies the requirements and test methods for concrete modular elements.

\section{Materials and Methods}

Two different experimental paving blocks were tested: one (labelled PBP) entirely produced with alkali-activated waste basalt powder and a second one (labelled PBA) with the same synthetic paste but with the addition of aggregates according to a specific grading distribution. 
The alkali-activation process is a synthesis between two groups of materials: precursors and activators. The result of this process is a cementitious-like material with final properties and performance related to the chemical composition of its constituents [40]. Thus, the properties of activators and precursors are fundamental for the quality of the final alkali-activated material (AAM). Well-established literature verified suitable mechanical performance for AAMs produced with precursors rich in silica and alumina, in strong alkaline conditions generated by specific activators [41,42]. AAMs are today considered a sustainable alternative to Portland cement, considering the relatively low environmental footprint of the production process [43]. Furthermore, if properly designed, the chemical and mechanical property of the material, as well as its durability, are considerably higher if compared to traditional cement concrete.

\subsection{Precursors}

In this experimental application, a waste basalt powder (B) and metakaolin (M) were used as precursors according to a specific mix design.

$\mathrm{B}$ is a material completely passing the $0.005 \mathrm{~mm}$ sieve and it is a waste from the basalt extraction process in quarries. Today, this material is landfilled and its re-use can represent an eco-friendly solution to its disposal. Furthermore, the use of basalt in the alkali-activation process has been scientifically proven by several studies $[44,45]$.

$\mathrm{M}$ is obtained by the thermal treatment of kaolin and its adoption for the synthetic process dates back to the first AA applications. Considering the chemical composition of $\mathrm{M}$, it is widely used in order to improve the mechanical and durability properties of the final product [46].

The chemical properties of both precursors are summarized in Table 1.

Table 1. Chemical properties of basalt and metakaolin.

\begin{tabular}{cccc}
\hline Compound & Unit & Basalt & Metakaolin \\
\hline $\mathrm{SiO}_{2}$ & $\% \mathrm{p} / \mathrm{p}$ & 45.3 & 55.2 \\
$\mathrm{CaO}$ & $\% \mathrm{p} / \mathrm{p}$ & 8.8 & 0.2 \\
$\mathrm{Na}_{2} \mathrm{O}$ & $\% \mathrm{p} / \mathrm{p}$ & 1.7 & 0.6 \\
$\mathrm{Al}_{2} \mathrm{O}_{3}$ & $\% \mathrm{p} / \mathrm{p}$ & 21.6 & 40.3 \\
$\mathrm{Fe}_{2} \mathrm{O}_{3}$ & $\% \mathrm{p} / \mathrm{p}$ & 8.5 & 1.4 \\
$\mathrm{SO}_{3}$ & $\% \mathrm{p} / \mathrm{p}$ & $<0.1$ & 0.2 \\
$\mathrm{MgO}$ & $\% \mathrm{p} / \mathrm{p}$ & 2.0 & 0.1 \\
$\mathrm{P}_{2} \mathrm{O}_{5}$ & $\% \mathrm{p} / \mathrm{p}$ & 0.7 & $<0.1$ \\
$\mathrm{TiO}_{2}$ & $\% \mathrm{p} / \mathrm{p}$ & 0.2 & 1.5 \\
$\mathrm{ZnO}$ & $\% \mathrm{p} / \mathrm{p}$ & $<0.1$ & $<0.1$ \\
$\mathrm{~K}_{2} \mathrm{O}$ & $\% \mathrm{p} / \mathrm{p}$ & 9.7 & 0.2 \\
\hline
\end{tabular}

\subsection{Activators}

The activators are needed in order to create the strong alkaline environment suitable for the chemical reaction. Taking as a reference, the well-established literature review and previous experimental studies, the liquid mix used as an activator was a blend of Sodium Silicate (SS) and Sodium Hydroxide (SH). SS is a commercial product with $\mathrm{SiO}_{2} / \mathrm{Na}_{2} \mathrm{O}$ ratio equal to 1.99 , while $\mathrm{SH}$ was prepared with a molarity fixed at 10 .

Being the chemical properties crucial for the performance of the final material, different activator blends were produced in terms of ratio between SS and $\mathrm{SH}$.

\subsection{Research Plan}

The research plan can be divided into two steps: the first is related to the characterization of the alkali-activated paste, while the second phase is about the laboratory characterization of the experimental paving blocks. 
The evaluation of the quality of the alkali-activated paste was based on mechanical tests. It is worth noting, that there are no specific test methods or standardized procedures for the characterization of AAMs. Thus, the mechanical analysis was carried out in terms of compressive strength on cubic samples, in compliance with the EN 1015-1 standard, which is traditionally taken as a reference for hardened mortar.

Once the correct mix design for the AAM was defined, two different mixes for paving blocks were prepared, with and without aggregates. The material was casted in plastic rectangular, specific for the production of interlocking modular elements. The following physical, mechanical and functional characterization was based on tests specified in the EN 1338 standard. This European Standard identifies the material requirements and the test protocols and methods for concrete paving blocks. Considering the wide range of applications of modular elements, their performance requirements are defined by the standard in terms of classes and associated marking designations.

Therefore, according to the reference classes, a concrete paving block is considered suitable for its specific application (i.e., road pavement, pedestrian use, parking areas, etc.).

The following tests were carried out on the experimental samples:

- Shape and dimensions;

- Weathering resistance in terms of water absorption;

- Tensile splitting strength;

- Abrasion resistance;

- Slip/skid resistance.

Based on data and on the resulting classification, the experimental paving blocks could be suitable for specific real applications.

\section{Alkali-Activated Material Characterization}

As previously stated, the characterization of AAMs is generally based on mechanical tests performed in compliance with reference standards for common construction materials, due to the lack of specific tests methods.

In the case under study, the evaluation of the quality of the AA pastes was based on the compressive strength of $40 \times 40 \mathrm{~mm}$ cubic samples. The reference standard is the EN 1015-1, which is commonly used for hardened mortars. According to the aforementioned standard, the compressive strength is calculated applying an increasing load (from $50 \mathrm{~N} / \mathrm{s}$ to $500 \mathrm{~N} / \mathrm{s}$ ) on cubic samples, so that the failure occurs in a range from 30 to $90 \mathrm{~s}$. The maximum load is registered and used for the calculation of the compressive strength.

Different mixtures were prepared, according to the following variables:

- Dosage of waste basalt powder and metakaolin;

- $\quad$ Dosage of SS and SH;

- Precursors/Activators ratio;

- Curing time and procedure.

The right mix design was chosen in terms of workability, mechanical properties and low environmental impact curing conditions.

After several trials, the mix design considered the $70 \%$ of waste basalt powder and $30 \%$ of metakaolin as precursors mix. The SS/SH ratio for the activator was fixed equal to 4 , while the precursors/activators ratio was 0.75 . Once mixed, the AA paste was casted in $40 \times 40 \mathrm{~mm}$ cubic molds and one day in the oven at $70{ }^{\circ} \mathrm{C}$ was chosen as optimized curing conditions. In order to have a complete mechanical characterization of the AA mixture, the compressive strength tests were carried out after 3, 7, 14, 21 and 28 days of curing.

The mechanical results are presented in Table 2. 
Table 2. Compressive strength results for the alkali-activated (AA) cubic samples.

\begin{tabular}{cccccc}
\hline Compressive Strength (MPa) & Day 3 & Day 7 & Day 14 & Day 21 & Day 28 \\
\hline Sample 1 & 45 & 61 & 60 & 59 & 63 \\
Sample 2 & 49 & 61 & 62 & 61 & 64 \\
Sample 3 & 48 & 63 & 57 & 59 & 64 \\
Sample 4 & 46 & 59 & 57 & 57 & 65 \\
AVG. & $\mathbf{4 7}$ & $\mathbf{6 1}$ & $\mathbf{5 9}$ & $\mathbf{5 8}$ & $\mathbf{6 4}$ \\
\hline
\end{tabular}

The AA mixture highlighted a remarkable compressive strength if compared to common Portland cement concrete after just 3 days of curing. However, a light deflection of the mechanical properties is registered for samples cured from day 7 to day 28 . This reduction does not affect the performance of the material and, based on results, the complete curing of the experimental mixture can be considered as concluded after 7 days. Furthermore, a slight variation in mechanical results is a common phenomenon for AAMs, due to the high influence of mixing and casting operations on the final performances of the material.

\section{Paving Blocks Characterization}

Once defined the final mix design and the curing conditions, the AA paste was used for the production of the experimental paving blocks. Two versions of the modular element were produced. The PBP was entirely made in AA mixture, while PBA was mixed with aggregates, according to a specific grading distribution, and the experimental AA paste as binder.

Figure 1 shows the particles size distribution, which fits with the gradation band commonly used for concrete paving blocks. Common limestone aggregates suitable for construction materials were used. They were mixed together with the AA paste according to a specific ratio in order to have a suitable workability of the final material.

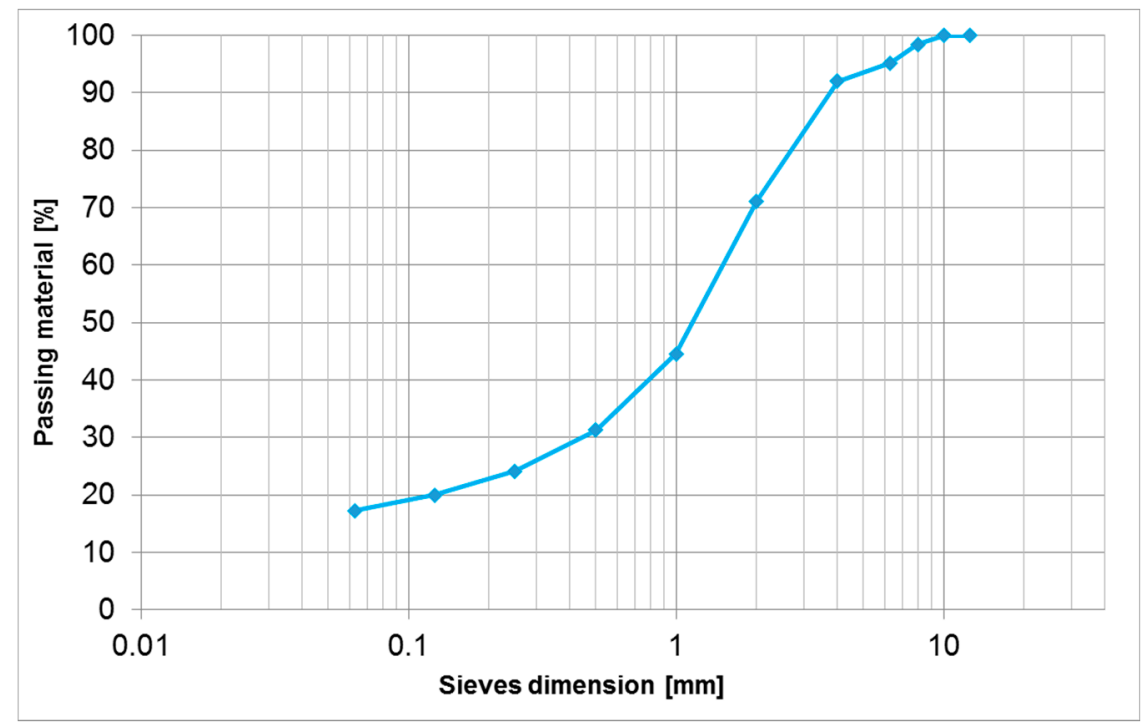

Figure 1. Grading distribution for Paving Block Aggregates (PBA).

The aggregates were mixed with the AA paste in order to improve the mechanical properties of the final mixture and to evaluate whether or not the presence of aggregates could affect the performance of the experimental paving blocks.

Once mixed or not with aggregates, the resulting material was casted in plastic molds, specific for the production of concrete interlocking modular elements. As defined during the mix design phase, the material was cured into the oven at $70{ }^{\circ} \mathrm{C}$ for $24 \mathrm{~h}$. The obtained paving blocks were than de-molded 
with the injection of compressed air. The samples were than stored for seven days before being tested in order to achieve the maximum of their mechanical properties, as verified during the preliminary AAMs characterization.

The plastic mold and the final samples are shown in Figure 2.

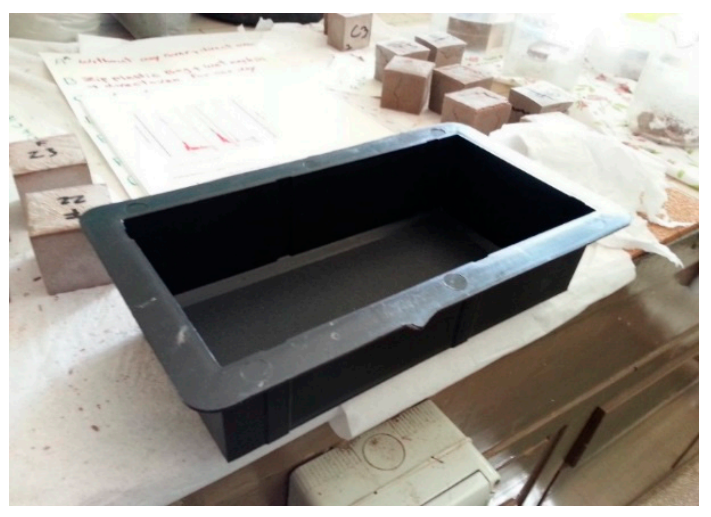

(a)

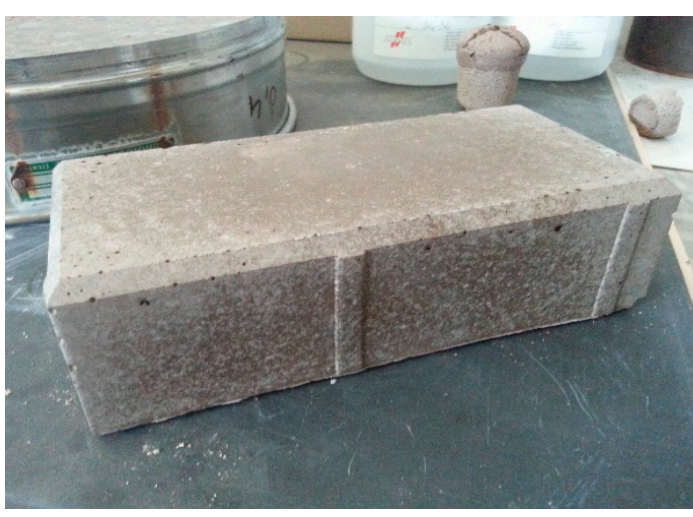

(b)

Figure 2. (a) Plastic mold; (b) Final paving blocks after de-molding.

In the following paragraphs, based on EN 1338 standard, the laboratory characterization of the experimental paving blocks is presented.

\subsection{Geometrical Properties, Visual Aspect And Physical Properties}

The geometrical measurement of the paving blocks is considered a compulsory test in order to verify the production consistency of the paving blocks. According to the Annex C of the EN 1338 standard, the thickness of a block is measured to the nearest millimeter. The maximum difference between the readings is calculated and recorded. Five experimental paving blocks were tested for each product.

The standards specify permissible deviations based on the product dimensions. In the case under the study, the paving blocks dimensions, the differences between measurements and the permissible deviations are reported in Table 3.

Table 3. Paving blocks measurements and deviations.

\begin{tabular}{cccc}
\hline Measurement & Length $\mathbf{( m m})$ & Width $\mathbf{( m m )}$ & Thickness $(\mathbf{m m})$ \\
\hline PBP & 200 & 100 & 60 \\
PBP deviations & \pm 1 & \pm 1 & \pm 2 \\
PBA & 200 & 100 & 60 \\
PBA deviations & \pm 2 & \pm 2 & \pm 2 \\
Permissible deviations & \pm 2 & \pm 2 & \pm 3 \\
\hline
\end{tabular}

According to the results, both experimental products are in line with the requirements suggested by the standard. This is a further confirmation of the workability of the AA mixture, which allows the complete filling and the perfect adhesion of the material to the mold profile. Furthermore, the addition of aggregates does not substantially affect these properties.

However, the visual inspection of the paving blocks highlighted the presence of a small amount of surface bubbles. This is mainly due to the casting operations that should be improved in order to dissipate the air trapped into the mixture during the production.

In terms of physical characterization, as imposed by the standard, the paving blocks are classified according to their weight per square meter. The PBP has a theoretical weight of $105 \mathrm{~kg} / \mathrm{m}^{2}$, while the presence of aggregates makes the PBA equal to $115 \mathrm{~kg} / \mathrm{m}^{2}$. The most common concrete paving blocks range between $120-180 \mathrm{~kg} / \mathrm{m}^{2}$. 


\subsection{Water Absorpition}

According to the EN 1338 standard (Annex E), the weathering resistance is determined in terms of freeze-thaw resistance or water absorption. In the case under study, the water absorption was evaluated.

This test is very important for footpath paving materials considering their exposure to weather conditions. Still, this also represents an indirect evaluation of the air voids content of the material, being the porosity directly responsible for the level of saturation of the paving blocks when submerged in water. To evaluate the water absorption, in compliance with the standard, the specimens are immersed in potable water at a temperature of $(20 \pm 5){ }^{\circ} \mathrm{C}$ until a constant mass is reached. Once saturated, the paving blocks are than oven dried to constant mass. The water absorption is than calculated as the ratio between the block weight before and after saturation.

Average results are summarized in Table 4.

Table 4. Water absorption tests results and standard limits.

\begin{tabular}{cc}
\hline Paving Blocks & Water Absorption (\%) \\
\hline PBP & $14 \pm 1$ \\
PBA & $10 \pm 0$ \\
EN 1338 limit & $<6 \%$ (Class 1-Mark B) \\
\hline
\end{tabular}

It is worth noting, that the EN 1338 standard transfers to a national level, the durability requirements in terms of classes of weathering resistance. However, the maximum suggested water absorption limit is fixed to $6 \%$. Both experimental paving blocks exceed the proposed limit. This is related to the porosity of the material, which was also highlighted from the visual analysis of the paving blocks' surfaces. However, the presence of aggregates within the AA mixture seems to reduce the water absorption. The improvement of the mixing and casting operations might reduce the porosity of the paving blocks and consequently their water absorption.

\subsection{Tensile Splitting Strength}

The tensile splitting strength represents the only test required by the EN 1338 (Annex F) standard for the mechanical characterization of the concrete paving blocks. According to the standard, the load is applied through two steel blades of a specified size on a sample, and it is progressively increased at a rate equal to $0.05 \mathrm{MPa} / \mathrm{s}$. Consequently, the failure load is registered and the area of the failure planes is calculated. The tensile splitting strength is than calculated according to the following equation:

$$
T=0.637 \cdot k \cdot \frac{P}{S}
$$

where $k$ is a correction factor dependent on the block thickness, $P$ is the failure load, while $S$ is the area of the failure.

The failure load per unit length $(\mathrm{F})$ is also required and calculated as the ratio between the failure load and failure length measured at the top and at the bottom of the paving block. According to the test procedure, the samples are kept in a water bath at $20^{\circ} \mathrm{C}$ for $24 \mathrm{~h}$ before testing.

Three samples were tested for each product and results are presented in Table 5.

As for the reference standard limits, the average characteristic tensile splitting strength required should not be less than $3.6 \mathrm{MPa}$, but none of the samples can register a mechanical value lower than 2.9 MPa and a failure load per unit length lower than $250 \mathrm{~N} / \mathrm{mm}$.

In the case under study, only the PBA exceeds the standard requirements. This is due to the presence of aggregates within the AA mixture, which improves the structural properties of the paving block, as well as its cohesion, if compared to PBP. In this case, the absence of a lithic skeleton makes the structure weak for tensile splitting strength even if the compressive strength verified in the previous lab characterization on cubic samples was considerably high. 
Table 5. Tensile splitting test results and limits.

\begin{tabular}{ccc}
\hline Paving Blocks & T (MPa) & F (N/mm) \\
\hline PBP 1 & 2.4 & 256 \\
PBP 2 & 1.7 & 182 \\
PBP 3 & 2.2 & 237 \\
Avg. PBP & 2.1 & 225 \\
PBA 1 & 4.2 & 456 \\
PBA 2 & 3.6 & 389 \\
PBA 3 & 3.2 & 344 \\
Avg. PBA & 3.7 & 396 \\
EN 1338 limit & $>3.6 \mathrm{MPa}$ & $>250 \mathrm{~N} / \mathrm{mm}$ \\
\hline
\end{tabular}

\subsection{Abrasion Resistance}

The abrasion resistance is generally considered the ability of a surface to withstand the friction action. This is an important property for paving materials considering that it is directly related to their durability, as well as to the functional properties of the surface.

This property of the paving blocks is evaluated through the Wide Wheel Abrasion test. According to the standard, the abrasive force is generated by an abrasive material, which flows on a rotating wheel that acts on the paving blocks surface (EN 1338, Annex G) (Figure 3).

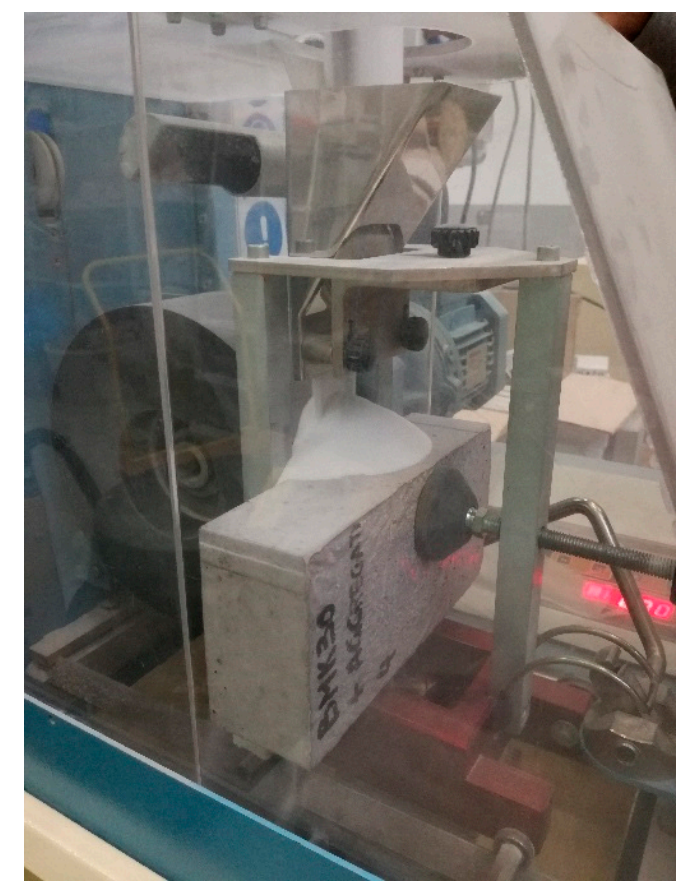

Figure 3. Wide Wheel Abrasion test on Paving Block Paste (PBP) sample.

The abrasive material is a corundum powder with a specific particles size and its flow onto the abrasion wheel with a minimum rate of $2.5 \mathrm{~L} / \mathrm{min}$. The wheel is made of specific Brinnel hardness steel and it rotates on the paving block surface according to 75 revolutions in $60 \mathrm{~s}$. Furthermore, the sample is clamped in order to stay always in contact with the abrasive wheel during the test. After 75 revolutions, the surface of the paving block is cleaned and the dimension of the groove is registered. The EN 1338 standard classifies and marks the concrete paving blocks according to the groove dimensions.

Three samples were tested for every material and the results are presented in Table 6 . 
Table 6. Abrasion tests results and classification according to the EN 1338 standard.

\begin{tabular}{ccc}
\hline Paving Blocks & Groove Dimensions $(\mathbf{m m})$ & EN 1338 Classification \\
\hline PBP 1 & 22.4 & - \\
PBP 2 & 23.6 & - \\
PBP 3 & 25.7 & Class 1-Mark F \\
Avg. PBP & 24 & - \\
PBA 1 & 22.7 & - \\
PBA 2 & 22.7 & - \\
PBA 3 & 23.6 & Class 3-Mark H \\
Avg. PBA & 23 & \\
\hline
\end{tabular}

According to the results, the two experimental products have different class and mark, considering the higher abrasion resistance properties for the PBA. For traditional concrete paving blocks, the abrasion resistance is strictly related to the curing conditions, to the surface finishing or to the mix design (i.e., aggregates hardness, binder quality, and aggregates-paste ratio). In the case presented here, the only variable between the materials was the presence of aggregates for PBA, which seems to improve the abrasion resistance characteristics of the paving blocks.

\subsection{Slip/skid Resistance}

The skid resistance can be considered as one of the most important functional properties of a paved surface being directly responsible for the safety of the users. In compliance with the EN 1338 standard (Annex I), the slip/skid resistance is evaluated in terms of Unpolished Slip Resistance Value (USRV). This is a measure of the quality of the paving blocks and it determines whether the particular surface finish is appropriate for the proposed application.

The pendulum friction tester is proposed for the evaluation of the skid resistance. The friction force offered by a wetted surface to a rubber slider sliding on it, is measured in terms of reduction in length of the slider swing using a calibrated scale on the equipment (Figure 4).

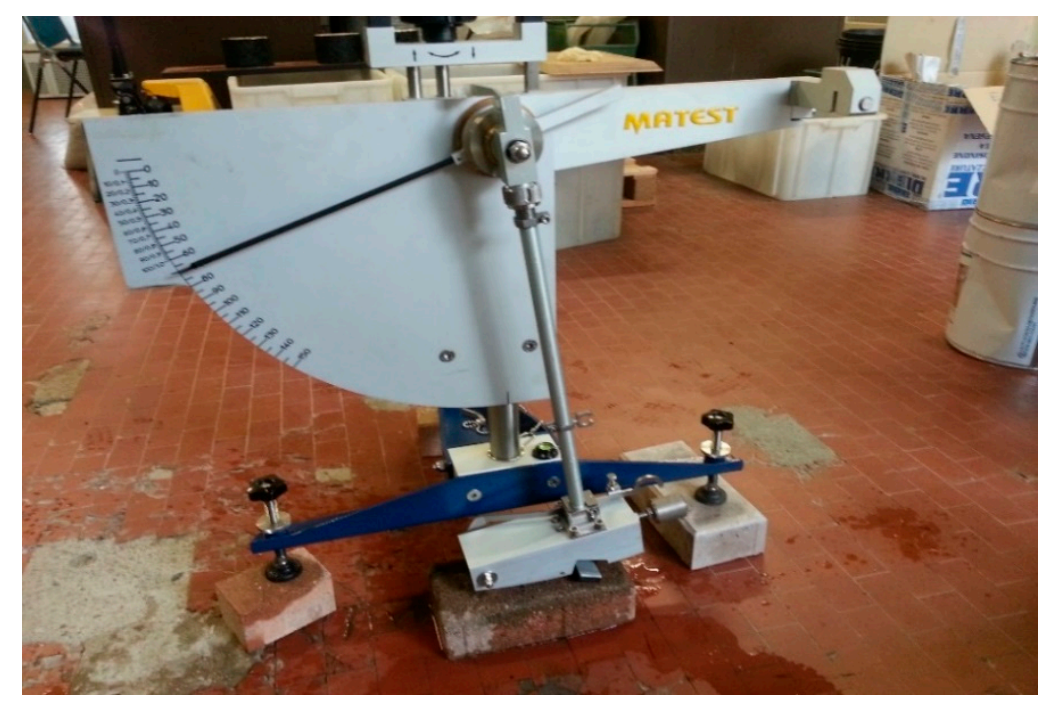

Figure 4. Pendulum friction tester during the skid resistance tests on concrete paving blocks.

Considering that the friction force can be affected by the materials temperature, the test equipment, complete with rubber slider, is kept at $20^{\circ} \mathrm{C}$ for at least $30 \mathrm{~min}$ immediately before performing the test. At the same time, the samples are kept in a water bath at $20^{\circ} \mathrm{C}$ for $30 \mathrm{~min}$. Three paving blocks were tested for each material and the results are shown in Table 7. 
Table 7. URSV tests results.

\begin{tabular}{cc}
\hline Paving Blocks & USRV \\
\hline PBP 1 & 60 \\
PBP 2 & 62 \\
PBP 3 & 63 \\
Avg. PBP & 62 \\
PBA 1 & 56 \\
PBA 2 & 51 \\
PBA 3 & 53 \\
Avg. PBA & 54 \\
\hline
\end{tabular}

The results highlighted higher skid resistance for the PBPs. In this case, the presence of aggregates does not improve the performance of the material, which instead are reduced. All in all, the URSV values are remarkably high for both experimental materials. It is worth noting, that the EN 1338 standard does not fix limitations or threshold values in terms of slip/skid resistance. The most common paving blocks have a minimum URSV value equal to 35 and some UK technical guidelines identify the range between 40 and 79 USRV as "low potential for slip" [47]. Thus, the experimental paving blocks show considerable skid resistance properties.

In the case under examination, the surface texture was giving by the mold, that had specific texture on the walkable surface of the modular element. The presence of aggregates has probably reduced the viscosity of the AA mixture, as a consequence, its perfect distribution on the mold profile needed to imprint the texture on the cured surface.

\section{Conclusions}

An alternative interlocking modular element produced with alkali-activated waste basalt powder is presented in this paper. Two different products were designed, produced and tested, with and without aggregates. Taking into account the EN 1338 standard for concrete paving blocks, a complete laboratory characterization of the experimental blocks is proposed.

Based on the data presented in this paper, several conclusions and comments can be drawn:

The chemical predisposition of the waste basalt powder for the alkali-activation process has been verified. This is further confirmation of previous research presented by the author. Furthermore, the adopted mix design seems to be suitable for the production of a mixture with adequate workability and mechanical properties to be used as a paste for the casting of modular elements.

The alternative paving blocks without aggregates (PBP) do not comply with some of the requirements of the EN 1338 standard. Despite the AA paste ensuring a perfect casting, the tensile splitting strength, as well as the water absorption of the samples, are limited. The mechanical properties are not enough, despite the high compressive strength results obtained during the AA paste characterization.

The presence of aggregates within the paving block is fundamental in order to achieve the tensile splitting strength required by the EN 1338 standard. As a downside, the addition of particles within the AA paste slightly reduces the workability and casting operations and limits the full adhesion of the mortar to the mold profile. This phenomenon was confirmed through the verification of the shape, superficial texture and dimensions of the paving blocks. However, the dimension's deviations were in line with the acceptance limits imposed by the reference standard.

In the light of the presented laboratory results, the production of paving blocks through the alkali-activation of waste basalt powder seems to be a viable alternative for interlocking modular elements. However, the presence of aggregates according to a specific grading distribution is needed to achieve the required mechanical properties. Furthermore, the optimization of the particles distribution and the paste/aggregates ratio would improve the workability properties of the mixture and the casting operations. Still, the use of vibrating tables during the molding phase could improve the quality of 
the final product, reducing the presence of trapped air in the mixture. It may convert the laboratory production to an industrial scale.

In an eco-friendly perspective, further studies will have to focus on the production and characterization of AA paving blocks from waste powders with recycled aggregates in order to achieve fully recycled and sustainable modular elements.

Funding: This research received no external funding.

Acknowledgments: Basalti Orvieto srl supplied the waste basalt powder for the research.

Conflicts of Interest: The authors declare no conflict of interest.

\section{References}

1. Artmann, M.; Inostroza, L.; Fan, P. Urban sprawl, compact urban development and green cities. How much do we know, how much do we agree? Ecol. Indic. 2019, 96, 3-9. [CrossRef]

2. Seto, K.C.; Güneralp, B.; Hutyra, L.R. Global forecasts of urban expansion to 2030 and direct impacts on biodiversity and carbon pools. Proc. Natl. Acad. Sci. USA 2012, 109, 16083-16088. [CrossRef] [PubMed]

3. Anastasiadou, K.; Vougias, S. "Smart" or "sustainably smart" urban road networks? The most important commercial street in Thessaloniki as a case study. Transp. Policy 2019, 82, 18-25. [CrossRef]

4. Ng, C.P.; Law, T.H.; Jakarni, F.M.; Kulanthayanc, S. Relative improvements in road mobility as compared to improvements in road accessibility and urban growth: A panel data analysis. Transp. Res. Part A Policy Pract. 2018, 117, 292-301. [CrossRef]

5. Gullotta, T.M.; Mistretta, M.; Praticò, F. A life cycle scenario analysis of different pavement technologies for urban roads. Sci. Total Environ. 2019, 673, 585-593. [CrossRef] [PubMed]

6. Tsiotas, D.; Polyzos, S. The topology of urban road networks and its role to urban mobility. Transp. Res. Procedia 2017, 24, 482-490. [CrossRef]

7. Lyu, X.; Han, Q.; de Vries, B. Procedural modeling of urban layout: Population, land use, and road network. Transp. Res. Procedia 2017, 25, 3333-3342. [CrossRef]

8. Harsha, G.; Thoradeniya, B.; Halwatura, R. Public perceptions on urban outdoor constructions and their materials. In Proceedings of the 8th International Conference of Faculty of Architecture Research Unit (FARU); University of Moratuwa: Colombo, Sri Lanka, 2015; pp. 1-12.

9. Celauro, C.; Corriere, F.; Guerrieri, M.; Lo Casto, B. Environmentally appraising different pavement and construction scenarios: A comparative analysis for a typical local road. Transp. Res. Part D Transp. Environ. 2015, 34, 41-51. [CrossRef]

10. Di Mascio, P.; Moretti, L.; Capannolo, A. Concrete block pavements in urban and local roads: Analysis of stress-strain condition and proposal for a catalogue. J. Traffic Transp. Eng. 2019. [CrossRef]

11. Mudiyono, R.; Nor, H.M.; Hainin, M.R.; Ling, T.-C. Performance of concrete paving blocks pavement on sloped road section. Int. J. Pavement 2007, 6, 136-145.

12. Mendoza, J.-M.F.; Oliver-Solà, J.; Gabarrell, X.; Rieradevall, J.; Josa, A. Planning strategies for promoting environmentally suitable pedestrian pavements in cities. Trans. Res. D Trans. Environ. 2012, 17, 442-450. [CrossRef]

13. Sun Poon, C.; Chan, D. Paving blocks made with recycled concrete aggregate and crushed clay brick. Constr. Build. Mater. 2006, 20, 569-577. [CrossRef]

14. Hengl, H.L.; Füssl, J. The influence of superelevated profiles of paving block structures on their load-bearing behavior. Eng. Struct. 2016, 117, 195-203. [CrossRef]

15. Bhuvaneshwari, P.; Priyadharshini, U.; Gurucharan, S.; Mithunram, B. Strength characteristics of lightweight concrete blocks using mineral admixtures. IOP Conf. Ser. Earth Environ. Sci. 2017, 80, 012003. [CrossRef]

16. Elizondo-Martinez, E.-J.; Andrés-Valeri, V.C.; Jato-Espino, D.; Rodriguez-Hernandez, J. Review of porous concrete as multifunctional and sustainable pavement. J. Build. Eng. 2020, 27, 100967. [CrossRef]

17. Giustozzi, F. Polymer-modified pervious concrete for durable and sustainable transportation infrastructures. Constr. Build. Mater. 2016, 111, 502-512. [CrossRef]

18. Shan, J.S.; Li, H.; Jiang, H.W. Mechanical characteristics and design method of interlocking concrete block pavement. J. Traffic Transp. Eng. 2015, 15, 9-17. 
19. International Energy Agency and the United Nations Environment Programme. 2018 Global Status Report: Towards a Zero-Emission, Efficient and Resilient Buildings and Construction Sector; International Energy Agency and the United Nations Environment Programme: Katowice, Poland, 2018.

20. Kutnik, M.; Suttie, E.; Brischke, C. Durability, efficacy and performance of bio-based construction materials: Standardisation background and systems of evaluation and authorisation for the European market. In Performance of Bio-based Building Materials; Elsevier: Amsterdam, The Netherlands, 2017; pp. 593-610. [CrossRef]

21. Tataranni, P.; Sangiorgi, C.; Simone, A.; Vignali, V.; Lantieri, C.; Dondi, G. A laboratory and field study on 100\% Recycled Cement Bound Mixture for base layers. Int. J. Pavement Res. Technol. 2018, 11, 427-434. [CrossRef]

22. Franzoni, E.; Volpi, L.; Bonoli, A.; Spinelli, R.; Gabrielli, R. The environmental impact of cleaning materials and technologies in heritage buildings conservation. Energy Build. 2018, 165, 92-105. [CrossRef]

23. Van den Heede, P.; de Belie, N. Environmental impact and life cycle assessment (LCA) of traditional and "green" concretes: Literature review and theoretical calculations. Cem. Concr. Compos. 2012, 34, 431-442. [CrossRef]

24. Sormunen, P.; Kärki, T. Recycled construction and demolition waste as a possible source of materials for composite manufacturing. J. Build. Eng. 2019, 24, 100742. [CrossRef]

25. Chen, W.; Jin, R.; Xu, Y.; Wanatowski, D.; Li, B.; Yan, L.; Pan, Z.; Yang, Y. Adopting recycled aggregates as sustainable construction materials: A review of the scientific literature. Constr. Build. Mater. 2019, 218, 483-496. [CrossRef]

26. Yap, S.P.; Goh, Y.; Mo, K.H.; Ibrahim, H.A. Recycling of Construction and Demolition Wastes into Renewable Construction Materials. In Reference Module in Materials Science and Materials Engineering; Elsevier: Amsterdam, The Netherlands, 2019.

27. Robayo-Salazar, R.A.; Fernando Rivera, J.; Mejía de Gutiérrez, R. Alkali-activated building materials made with recycled construction and demolition wastes. Constr. Build. Mater. 2017, 149, 130-138. [CrossRef]

28. Xiao, J.; Li, W.; Fan, Y.; Huang, X. An overview of study on recycled aggregate concrete in China (1996-2011). Constr. Build. Mater. 2012, 31, 364-383. [CrossRef]

29. Andrew, R.M. Global $\mathrm{CO}_{2}$ emissions from cement production, 1928-2017. Earth Syst. Sci. Data 2018, 10, 2213-2239. [CrossRef]

30. Tayeh, B.A.; Hasaniyah, M.W.; Zeyad, A.M.; Yusuf, M.O. Properties of concrete containing recycled seashells as cement partial replacement: A review. J. Clean. Prod. 2019, 237, 117723. [CrossRef]

31. Rashad, A.M. An overview on rheology, mechanical properties and durability of high-volume slag used as a cement replacement in paste, mortar and concrete. Constr. Build. Mater. 2018, 187, 89-117. [CrossRef]

32. Silva, R.V.; de Brito, J.; Dhir, R.K. Use of recycled aggregates arising from construction and demolition waste in new construction applications. J. Clean. Prod. 2019, 236, 117629. [CrossRef]

33. Soutsos, M.N.; Tang, K.; Millard, G.S. Use of recycled demolition aggregate in precast products, phase II: Concrete paving blocks. Constr. Build. Mater. 2011, 25, 3131-3143. [CrossRef]

34. Wang, L.; Chen, L.; Tsang, D.C.W.; Li, J.S.; Baek, K.; Hou, D.; Ding, S.; Sun Poon, C. Recycling dredged sediment into fill materials, partition blocks, and paving blocks: Technical and economic assessment. J. Clean. Prod. 2018, 199, 69-76. [CrossRef]

35. Gancel, O.; Ozel, C.; Koksal, F.; Erdogmus, E.; Martinez-Barrera, G.; Brostow, W. Properties of concrete paving blocks made with waste marble. J. Clean. Prod. 2012, 21, 62-70. [CrossRef]

36. Wattanasiriwech, D.; Saiton, A.; Wattanasiriwech, S. Paving blocks from ceramic tile production waste. J. Clean. Prod. 2009, 17, 1663-1668. [CrossRef]

37. Ganjian, E.; Jalull, G.; Sedeghi-Pouva, H. Using waste materials and by-products to produce concrete paving blocks. Constr. Build. Mater. 2015, 77, 270-275. [CrossRef]

38. Kumar, A.; Kumar, S. Development of paving blocks from synergistic use of red mud and fly ash using geopolymerisation. Constr. Build. Mater. 2013, 38, 865-871. [CrossRef]

39. Agyeman, S.; Obeng-Ahenkra, N.K.; Assiamah, S.; Twumasia, G. Exploiting recycled plastic waste as an alternative binder for paving blocks production. Case Stud. Constr. Mater. 2019, 11, e00246. [CrossRef]

40. Provis, J.L.; Van Deventer, J.S.J. Introduction to geopolymers. In Geopolymers; Elsevier: Amsterdam, The Netherlands, 2009; pp. 1-11. 
41. Pacheco-Torgal, F.; Castro-Gomes, J.; Jalali, S. Alkali-activated binders: A review: Part 1. Historical background, terminology, reaction mechanisms and hydration products. Constr. Build. Mater. 2008, 22, 1305-1314. [CrossRef]

42. Provis, J.L. Alkali-activated materials. Cem. Concr. Res. 2018, 114, 40-48. [CrossRef]

43. Rakhimova, R.N.; Rakhimov, R.Z. Toward clean cement technologies: A review on alkali-activated fly-ash cements incorporated with supplementary materials. J. Non-Cryst. Solids 2019, 509, 31-41. [CrossRef]

44. Tataranni, P.; Besemer, G.M.; Bortolotti, V.; Sangiorgi, C. Preliminary Research on the Physical and Mechanical Properties of Alternative Lightweight Aggregates Produced by Alkali-Activation of Waste Powders. Materials 2018, 11, 1255. [CrossRef]

45. Tataranni, P.; Sangiorgi, C. Synthetic Aggregates for the Production of Innovative Low Impact Porous Layers for Urban Pavements. Infrastructures 2019, 4, 48. [CrossRef]

46. Palomo, A.; Blanco-Varela, M.T.; Granizo, M.L.; Puertas, F.; Vazquez, T.; Gruzteck, M.W. Chemical stability of cementitious materials based on metakaolin. Cem. Concr. Res. 1999, 29, 997-1004. [CrossRef]

47. UK Slip Resistance Group. The Assessment of Floor Slip Resistance; Issue 2, RAPRA; UK Slip Resistance Group: Coventry, UK, 2000.

(C) 2019 by the author. Licensee MDPI, Basel, Switzerland. This article is an open access article distributed under the terms and conditions of the Creative Commons Attribution (CC BY) license (http://creativecommons.org/licenses/by/4.0/). 